Madimabe, M. P. \& Omodan, B. I. Investigating the Effects of E-Learning as A Method of Curriculum Dissemination for Rural TVET College Students

\title{
Investigating the Effects of E-Learning as a Method of Curriculum Dissemination for Rural TVET College Students
}

\author{
Makhosi P. Madimabe*1 \& Bunmi I. Omodan ${ }^{1}$ \\ *Corresponding Author: khosimadix@gmail.com \\ 1. University of the Free State, School of Education Studies, South Africa \\ Received : 2021-03-31 \\ Revised : 2021-06-22 \\ Accepted : 2021-07-30

\begin{abstract}
How to cite this paper: Madimabe, M. P. \& Omodan, B. I. (2021). Investigating the Effects of E-Learning as A Method of Curriculum Dissemination for Rural TVET College Students. Research in Social Sciences and Technology, 6(3), 82-92. https://doi.org/10.46303/ressat.2021.27
\end{abstract}

This is an Open Access article distributed under the terms of the Creative Commons Attribution 4.0 International license (https://creativecommons.org/licenses/by/4.0/).

\begin{abstract}
The study investigates the effects of e-learning as an alternative form of curriculum dissemination for rural Technical and Vocational Education and Training (TVET) college students. This study adopted connectivism theory, which enabled lecturers to reflect and adapt to how learning has changed and the accompanying implications of designing the spaces and structures to the current mode of learning. The researcher made use of two research methods to gather data; phone interviews and questionnaires. The data was analyzed using thematic analysis and the Statistical Package for Social Sciences (SPSS) Version 20.0, Office Word format. The results indicated that the unavailability of technological resources, lack of financial support from single parents' side due to socio-economic factors, and child-headed families hinder the correct implementation of e-learning and make it difficult to reach its objectives.
\end{abstract}

Keywords: E-learning; curriculum dissemination; TVET college; COVID-19; rural students

\section{Introduction}

Learning is continuous, never-ending and goes far beyond the realm of formal education in school, college or university (Shrivastava, 2018). Lecturing as a teaching method or style is still widely used from the primary, secondary and tertiary levels of education, of which vocational colleges are no different. Hence, according to McGrath (2012), there is a need to look into this issue to possibly change the education landscape in order to accommodate new teaching and learning methodologies. People of different socio-economic status (poor, black, employed, unemployed) use technology in different ways for various reasons and as a result, researchers see that internet web services like Google, Google Scholar, Facebook, WhatsApp, Telegram and others play important roles not just in connecting people through communication but also as sources of information education. In this instance, we concur with Shrivastava (2018), who said 
Madimabe, M. P. \& Omodan, B. I. Investigating the Effects of E-Learning as A Method of Curriculum Dissemination for Rural TVET College Students

that in the $21^{\text {st }}$ century, things like social media contain the facets of the internet in that they connect people (communication) and are favorites among school youth in terms of how they connect and share information in every corner of the world. Although this teaching and learning platform is a challenge in developing countries, Mässing (2017) argues that it is an alternative educational solution to unforeseen challenges such as community unrest, lockdown and natural disasters, as seen in the COVID-19 pandemic.

The observed vulnerability may be connected to limited educational resources in institutes as the major challenges of rural institutions in South Africa (Omodan et al., 2019). Andersson (2008) further adds that these susceptibility factors are persistent over time due to inadequate access to connectivity. Considering Zawacki-Richter and Qayyum (2019) assertions, many countries, especially those in the sub-Saharan, continue to struggle with making the complete transitioned by providing teaching and learning through educational technologies. One of the overarching challenges leading to this fact is poor government support, provision and maintenance of infrastructure, especially reliable power supply and costs, all of which derail efforts for transition to e-learning (in both urban and rural areas) and gives the researcher more clarity on the gap that is accompanied by this method of teaching and learning.

The COVID-19 pandemic has affected educational systems worldwide, leading to a near-total closure of schools, universities and TVET colleges (Okoye et al., 2021). It has led to the utilization of e-learning as an alternative route of teaching and learning as this route reflected the characteristics of no contact, which projected the safest attempt to reduce the spread of COVID-19. The researcher shares similar views with Omodan (2020), who believes that higher education institutions located in the rural areas of the Free State Province, Maluti -A-Phofung Municipality in South Africa seem to be vulnerable in the event of COVID-19 lockdown and community shutdown unrests in response to this alternative teaching and learning methodology. It is important to consider that students were locked down in their rural homes assumed to be in remote areas with little or no access to the internet, which came as a result of chronic unemployment, inequality, and poverty which are dominant in the rural communities of South Africa; conditions such as scarcity of educational resources should be acknowledged as an outcome. Adding to the list of obstacles, Okoye et al (2021) stated that the main challenge for lecturers is to equip students with processes or criteria's of how students can retain the learned content; how students can independently self-teach themselves continually and know methods that incorporate coping mechanisms and acceleration of education in general. One tend to concur with Kitizo (2016) when further outlining that, at times, the focus is on the usage of technology rather than on quality teaching and learning that this technology is disseminating, taking into consideration that only few higher education practitioners can use technology of this transformative era.

According to Zare et al. (2016), higher education institutions should be accountable to the public and should be responsive to the needs of their respective local communities. This entails equipping their primary stakeholders (students) with $21^{\text {st }}$-century knowledge and skills that will assist them to become responsible members of their communities and the country. However, this does not suggest that traditional teaching approaches such as lecturing have no space today; instead, things like e-learning can help close gaps that traditional teaching methods failed to address. Being in contrast with Omodan (2020), who holds that students are assumed 
Madimabe, M. P. \& Omodan, B. I. Investigating the Effects of E-Learning as A Method of Curriculum Dissemination for Rural TVET College Students

to lack access to the internet and other devices that can enable them to cope with alternative teaching and learning, which could be complete online teaching and learning; indeed, students lack such.

E-learning is defined as using electronic technologies to access educational curriculum (Salamat et al., 2018). In this paper, the researcher denotes e-learning as a process of acquiring and distributing knowledge widely across the world, enabling people around the world to access information. This study draws on Kamsin's (2005) belief that one of the greatest assets to online learning is its ability to allow students to control their learning process by offering students a direct, action-oriented, practical learning experience. Salamat et al. (2018) further added by stating that, this mode of learning makes education flexible for students because there are no boundaries of time and building. Letseka et al. (2018) stated that e-learning can be differentiated pedagogically; it can accommodate different learning styles, allowing students to work at their own pace and facilitate learning through a variety of activities. Self-regulated learning involves students' ability to engage proactively and work independently in an atmosphere that is self-motivating and encourages behavioral processes that increase goal attainment (Shrivastava, 2018).

\section{Theoretical framework}

This study is guided by the connectivism theory, making reference to flexibility of allowing learning to occur at any given time and space, depending on the recipient. Not only that, but its ability to influence shifts in education regarding the way knowledge and information flow, expand, and the changes brought by the increasing need for educational technologies in the realm of higher education (Picciano, 2017). The basic principles of this theory are that students need to understand and be provided with experiences in navigating and recognizing the perspective of the constantly shifting and evolving information. Connectivism theory is credited for its holistic principles that deliver a learning theory that properly fits within the digital age characterized by the diverse contexts identified in the introduction (Shrivastava, 2018). Proponents of connectivism say that the theory is beneficial because it allows for actionable knowledge whereby learners can exploit the weak ties among the nodes and adopt a pattern of learning. They can also formulate meaning as individuals, thus expanding their personal network (Herlo, 2019). As a theory, connectivism calls for the creation and the formulation of knowledge instead of its dissemination inside and between learners. Thus, Siemens (2005) proposes the following eight connectivist principles illustrated in Table 1.

The connectivist approach is convenient as it allows students to employ the free internet web resources present for access by every person (Bates, 2015). The unique role of the theory in this study is its ability to enable lecturers to reflect on how learning has changed and the accompanying implications to how they should design the spaces and structures of learning today (Siemens, 2006). From our perspective as researchers, we draw on Siemens (2005), who asserts that lecturers should be encouraged to be aware of their role to formulate, organize and perform, assess and adjust learning in its entirety not just for present generations but also for future ones either or without connectivism learning theory. We hold that lecturers or institutions of higher learning must play their part in expanding the knowledge base of teaching and learning, taking into account the potential benefits that e-learning may offer. Therefore, 
Madimabe, M. P. \& Omodan, B. I. Investigating the Effects of E-Learning as A Method of Curriculum Dissemination for Rural TVET College Students

this study aims to investigate the effects of e-learning on curriculum dissemination for TVET college students located in the rural areas of South Africa.

Table 1. Siemens' Eight Principles of Connectivism

1. Learning and knowledge rest in diversity of opinions.

2. Learning is a process of connecting specialized nodes or information sources.

3. Learning may reside in non-human appliances.

4. Capacity to know more is more critical than what is currently known.

5. Nurturing and maintaining connections is needed to facilitate continual learning.

6. Ability to see connections between fields, ideas, and concepts is a core skill.

7. Currency (accurate, up-to-date knowledge) is the intent of all connectivist learning activities.

8. Decision-making is itself a learning process. Choosing what to learn and the meaning of incoming information is seen through the lens of a shifting reality. While there is a right answer now, it may be wrong tomorrow due to alterations in the information climate affecting the decision.

\section{Research Question}

In order to response to the above problem, the following research question and objectives were raised to guide the study:

- How can rural TVET colleges optimize e-learning as a form of curriculum dissemination to students?

\section{Research Objectives}

Thus, based on the main research question, following objectives guided the study. That is, the study explores;

- possible conditions necessary for e-learning to be utilized as an alternative form of curriculum dissemination for rural TVET college students

- possible threats that could hinder a successful implementation of e-learning as a platform for curriculum dissemination.

\section{Research Methodology}

In order to gain insight into the effects of e-learning on students' learning and teachings at TVET college level, cell-phone interviews and online questionnaires were conducted with 50 student registered in the TVET college. This method of collecting data was chosen as it best suited the rules and regulations of the COVID-19 pandemic. Volunteer sampling technique was used to gather data from the respondent, the driving force being the conditions of the 2020 National Lockdown and the frustrations that students were enduring in the teaching and learning process. 50 student participant who were willing and available forwarded their cell phone 
Madimabe, M. P. \& Omodan, B. I. Investigating the Effects of E-Learning as A Method of Curriculum Dissemination for Rural TVET College Students

numbers from various programs WhatsApp groups utilized at the college for the scheduling of the interviews, whilst they completed the online questionnaire which consisted of a 5-Likert scale from strongly agree to strongly disagree and it comprised five items. This was done as a consequence of having posted all the aspects of the study in the college program WhatsApp groups for the purpose of recruitment, because these students were directly affected by this abrupt technological shift and needed to air their various experiences. The first data collection method was the one-on-one phone interviews and the second was that of a questionnaire with a set of carefully designed questions was used as another research tool for data collection. The qualitative data was analyzed using thematic analysis and quantitative data using the Statistical Package for Social Sciences (SPSS) Version 20.0, Office Word format, and central tendency measures, which are the statistical techniques of frequency and percentage score. The aforesaid research methodologies were deemed suitable in achieving the objective of the study by the researchers.

\section{Data Presentation and Analysis}

The data presented responds to the objectives of the study, and this was done under the following sub-themes: availability of technological resources to encourage e-learning in the rural areas, involvement of parents in the teaching and learning of TVET college students and students inconsistently focusing on the set objectives. This was represented in terms of literature review, direct quotation and graphical presentations.

\section{Findings and Discussions}

\section{Conditions necessary for the implementation of e-learning}

Effective teaching approaches encourage students to recognize connections between different ways of curriculum dissemination for rural college students (Jones, 2002). Lecturers should design classrooms and activities that assist students to construct knowledge internally rather than imposing knowledge on students (Mulaudzi, 2016). To this extent, Mulaudzi (2016) also proposes that students should access to interact with lecturers and classmates continuously in the classroom and at home to construct knowledge that makes sense to them, and this will be a positive feature of a democratic approach through which environmental education will emerge as students will become enthusiastic about learning. The success and implementation of e-learning depend on several factors, such as the availability of technological resources and parental involvement in their children's learning.

\section{Availability of technological resources to encourage e-learning in rural areas}

Emphasizing this position, Chahine (2013) states that curriculum dissemination should be done in various innovative ways. Gordon and Browne (2014) support the above view by stating that e-learning is concept orientated; as such, it can enhance students' interest in learning while at home. The researchers also declared this in the quantitative statement below:

S2: "The availability of technological resources on the students' side could enhance the teaching and learning process in the rural communities."

S1: "The use of technology in the teaching and learning process will encourage students to learn more." 
Madimabe, M. P. \& Omodan, B. I. Investigating the Effects of E-Learning as A Method of Curriculum Dissemination for Rural TVET College Students

S2 and S1 statements clarify that lecturers should try different strategies to have new generations gather technological confidence in their learning process. This study also agrees that meeting this condition becomes necessary for successfully implementing e-learning in the rural TVET colleges. In support of this is the qualitative data in Fig. 1 below, which indicates that only $14 \%$ of the college students have access to either computers or smartphones while $53 \%$ of the students have no access to computers or smartphone while learning through e-learning.

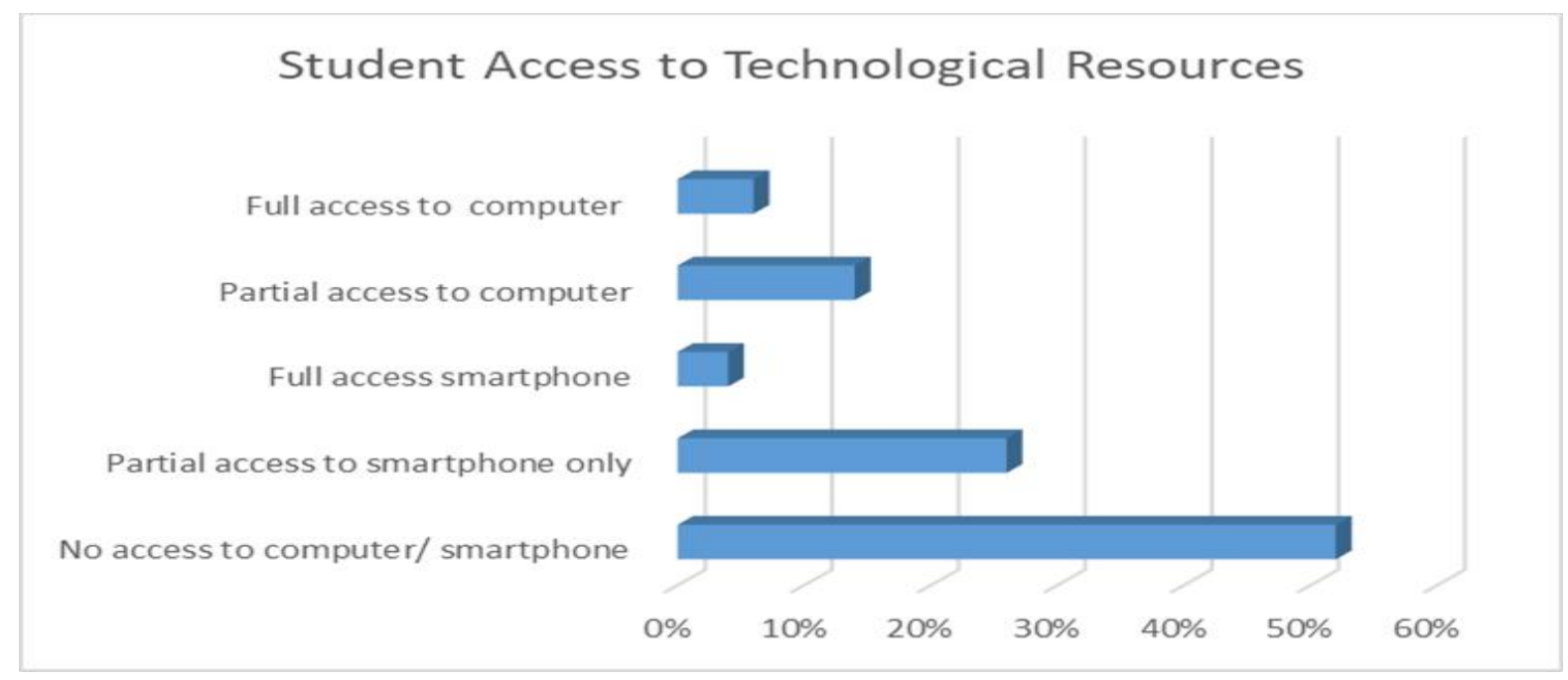

Figure 1. Students' access to technological resources

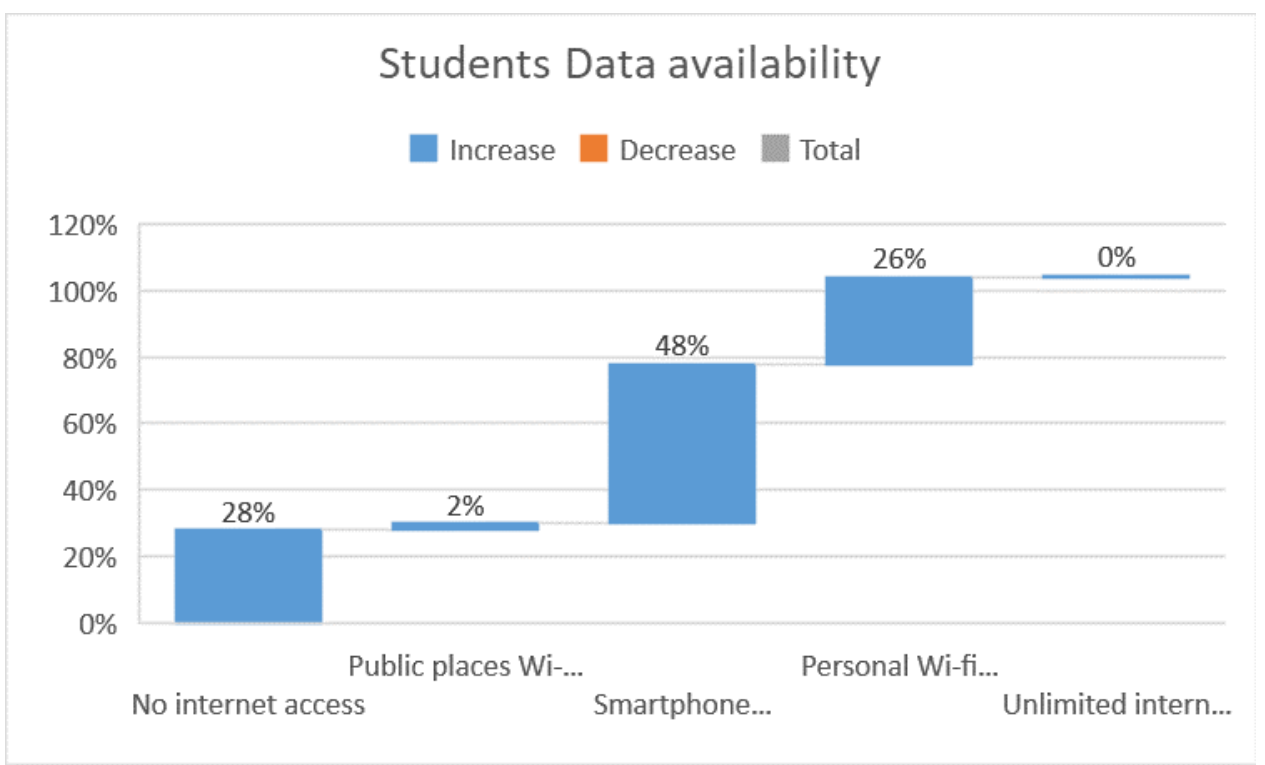

Figure 2. Students' accessibility to data

The figure above presents statistics that almost half of the students and more do not have access to computers or smartphones with connectivity when at home, which ultimately hinders the teaching and learning process. The figure denotes that no student at the college has 
Madimabe, M. P. \& Omodan, B. I. Investigating the Effects of E-Learning as A Method of Curriculum Dissemination for Rural TVET College Students

unlimited access to the internet. Only $26 \%$ of the students have access to persona Wireless Fidelity ( $\mathrm{Wi}-\mathrm{Fi}$ ), $48 \%$ of the students use smartphones to access data, while $28 \%$ on the student mass have no access to the internet.

The study found that the resources that should enable lecturers to plan their lessons, such as teaching aids and tangible resources that will assist lecturers in teaching authentic lessons, are regarded as a conducive condition. This will enable students to relate what is taught in the classroom to their everyday lives and that the assessments used when assessing their understanding of the questions must be similar to those examples done in class. In agreement with the findings, Moloi (2014) posits that a collective voice in the community can proffer a sustainable solution to the problems revealed; this voice can be in terms of the parents meeting the college halfway by procuring data, technological gadgets for students and creating a suitable environment for students to study at home.

\section{Involvement of parents in the teaching and learning of TVET college students}

Research has shown that most of the students' best performers at learning institutions are backed by their parent's participation and a high level of effort in their children's learning process. Parental involvement has many benefits because it enhances learners' motivation, interest and academic performance (Kwatubana \& Makhalemele, 2015). With parental involvement, learners become more social, are happier and active in their learning. These learners are less likely to be absent in school and tend to arrive on time, submit most of the homework and school projects, and their parents assist them in terms of confronting every hurdle in their school life (Kwatubana \& Makhalemele, 2015). This view is also supported by the participant below:

S3: "As part of the planning process, lecturers and parents need to work together in preparing students and determining how they wish to engage as peers."

According to S3's utterances, parents can assist their students and the college in various ways, such as waking the students up to be at college in time, tracking their daily awareness of what they are taught daily and help push students to do homework.

The above assertions agree with Sapungan and Sapungan (2014), who state that when a school has a strong relationship with their children's parents, it improves performance for both the children and their learners physically and academically. Parental involvement, therefore, is vitally important, school administrators (School Management Team SMT, School Governing Body SGBs and other stakeholders) are encouraged to emphasize the important role played by parental involvement and must make the college achieve its mission objectives. It becomes evident when viewing the qualitative data in the figure below that parental involvement plays a crucial point in supporting their student academically. Fig. 3 signifies that $89 \%$ of the students at the TVET college are still dependent on their parents' guidance and financial support, whereas only $11 \%$ of the students are from child-headed families.

As part of the planning process, the study found that lecturers and parents need to prepare students and determine how they wish to engage as peers. This is considered a conducive condition to the smooth implementation of e-learning in support of the stakeholders' findings in ensuring that students acquire knowledge meaningful to their lives which takes priority. 
Madimabe, M. P. \& Omodan, B. I. Investigating the Effects of E-Learning as A Method of Curriculum Dissemination for Rural TVET College Students

Llamas and Tuazon (2016) agree with the above by stating that parents become pleased when involved in the school's activities and their children's journey while at school, college or university. Findings from the study further indicate the vital importance of the relationship between parents and college administrators, which Ntekane (2018) says can result in the higher academic achievement of the school in all aspects (teaching and learning, management and administration). Park and Holloway (2013) further indicate that parents' involvement in their wards' schooling has long been believed to promote a range of positive outcomes, including academic achievement, engagement in schoolwork, and lower dropout rates.

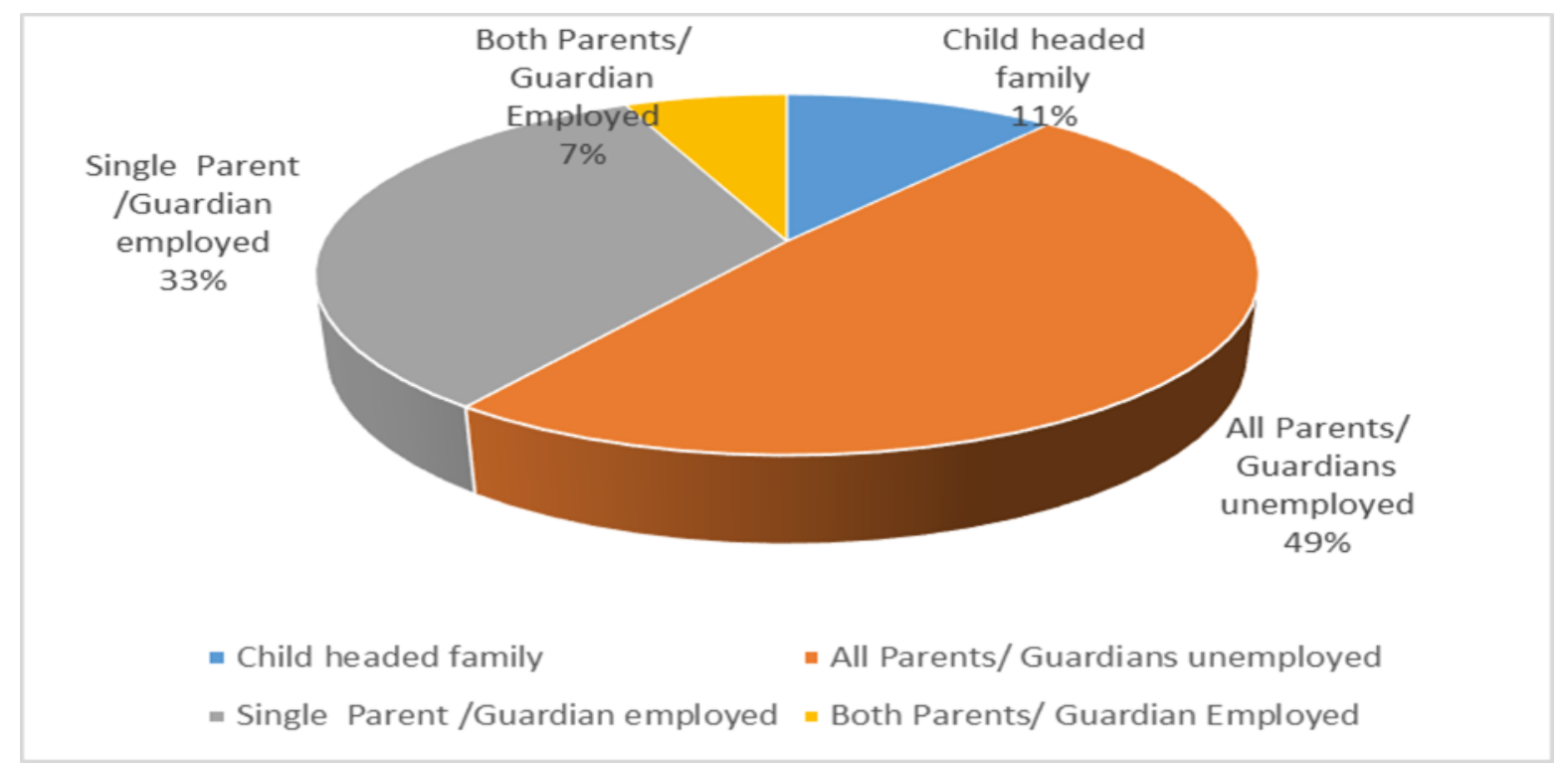

Figure 3. Home financial status

\section{A major threat that could evade the successful implementation of e-learning}

Given the condition necessary for the successful utilization of e-learning on curriculum dissemination in the colleges, the researchers' concerns were discussed and it was discovered that students inconsistently focus on the set objectives. The discussions were as follows:

\section{Students inconsistently focusing on the set objectives}

Students being in dire need of a consistent classroom environment. In order to achieve this goal, the learners and their teachers must work together in achieving the common collective goals of the institution. The students must collaborate with one another to make sure each module objectives are achieved. The students must be encouraged to embrace the challenges they come across in their learning and see them as a learning process rather than a stumbling block, as shown below:

FT: "Lack of participation may limit class interaction and also cause students to miss out on the benefits of student-centered undertakings, which include being exposed to multiple ways of analyzing, interpreting and solving problems." 
Madimabe, M. P. \& Omodan, B. I. Investigating the Effects of E-Learning as A Method of Curriculum Dissemination for Rural TVET College Students

From the above, it can be deduced that being in the classroom without sufficient knowledge to drive learning equates to taking a family vacation trip but with little knowledge of the destination route. Thus, the importance of lesson objectives can never be over emphasized because they ensure that the students' learning and the process are worthwhile and beneficial. When the lecturers lay out the lesson objectives from the start, they clearly indicate to their students what to expect and the direction of the subject or module. Communicating the lesson module also sends a clear message about the focus of learning activities, especially on their students' attention since it is needed based on the FT assertions.

The empirical data of this study found that students' inconsistent focus on the learning objectives is a threat; that is, students do not participate in the teaching and learning process. Ultimately, this limited class interaction also causes students to miss out on the benefits of student-centered undertakings, including being, and this automatically threatens the successful implementation of the strategy. Lecturers can overcome this threat by preparing and planning lessons to arouse students' curiosity and prompt students' interaction. Operative lecturers must be domain experts who understand how to flexibly use the availability of different technological pedagogues when disseminating content (Mahlomaholo \& Francis, 2011; Mahlomaholo, 2010). This paper agrees that clear learning objectives reassure students of the need to focus and provides lecturers with a focal point for planning instructions. In other words, feedback can assist in solidifying students' understanding of the content at hand and known specific lesson objectives will improve their performance in this way. The key for lecturers is to draw up clear learning objectives criteria to become aware of when they have achieved these learning objectives (Hattie \& Timperley, 2007). Equally, the lecturer must give feedback on each task, and the feedback must be in line with the learning objectives. The benefit of such feedback is that it will foster the students to be consistent in their learning, which aligns with the predetermined objectives.

\section{Conclusion and Recommendations}

According to the findings, there are few possibilities that e-learning can move swiftly in the colleges located in the rural areas of the Free State due to the following factors such insufficient learning gadgets and connectivity access. Secondly, in the environment where students are situated, load shedding occurs frequently due to the socio-economic development of the communities in which the college is located. Based on the findings, it has been observed that connectivity access is very limited to a certain percentage of students, resulting in students not getting all the shared information relevant for assessments and content coverage in time, which ultimately affects students' learning processes. On the other hand, it was also discovered that parents are not involved in their children's learning process. Discussions revealed that very limited support was observed as empirical data reflected that students do not have their privacy to a comfortable space at home; also, unemployment of either one or both parents hinders the financial aspect from the parents' side, which affects the students learning process. All in all, the study proposes that the colleges should work closely with the National Student Financial Aid Scheme (NSFAS) to ensure that students get the necessary support regarding the resources that will support e-learning, such as laptops, data connectivity and availability of WiFi on campus premises. The department of higher Education and Training (DHET) should ensure 
Madimabe, M. P. \& Omodan, B. I. Investigating the Effects of E-Learning as A Method of Curriculum Dissemination for Rural TVET College Students

that all colleges provide sufficient internet access for students to be able to connect to Wi-Fi on site.

\section{References}

Andersson, A. (2008). Seven major challenges for e-learning in developing countries: Case study eBIT, Sri Lanka. International Journal of Education and Development using ICT, 4, 45-62.

Bates, A.W. (2015). Teaching in a digital age. Available at https://teachonline.ca/sites/default/files/pdfs/teaching-in-a-digital-age 2016.pdf

Chahine, I.C. (2013). Mathematics teachers' exploration of indigenous mathematical knowledge systems through immersion in African cultures. I Congreso de Educacion Matematica de America Central y de El Caribe, 6-8 November 2013, Santo Domingo. Available at http://funes.uniandes.edu.co/4070/1/ChahineMathematicsCemacyc2013.pdf

Gordon, A.M., \& Browne, K.W. (2014). Beginnings and beyond: Foundations in early childhood education ( $2^{\text {nd }}$ ed.). Wadsworth Cengage Learning Publishers.

Herlo, D. (2019). Connectivism: A new learning theory? The European Proceedings of Social \& Behavioural Sciences, Edu World 2016 7th International Conference, 23, 330-337. https://www.europeanproceedings.com/article/10.15405/epsbs.2017.05.02.41

Jones, K. (2002). Issues in the teaching and learning of geometry. Aspects of teaching secondary mathematics: Perspectives on practice. Routledge Falmer.

Kamsin, A. (2005). Is e-learning the solution and substitute for conventional learning? International Journal of the Computer, the Internet and Management, 13(3), 79-89.

Kitizo, R. N. (2016). Connectivism in learning activity design: Implications for pedagogicallybased technology adoption in African higher education contexts. International Review of Research in Open and Distributed Learning, 17(2), 20-39

Kwatubana, S.J., \& Makhalemele, T.J., (2015). Parental involvement in the process of implementation of the National School Nutrition Pragramme in Public Schools. International journal of education sciences, 9(3),315-323.

Letseka, M., Letseka, M.M., \& Pitsoe, V. (2018). The challenges of e-learning in South Africa. Trends in E-learning, 8, 121-138.

Mässing, C. (2017). Success factors and challenges for e-learning technologies in the Namibian higher education system: A case study of the University of Namibia. Bachelor degree project in Information Systems Level ECTS, 1-47.

McGrath, S. (2021). Vocational education and training for development: A policy in need of a theory? International Journal of Educational Development, 32(5), 623-631. https://doi.org/10.1016/j.ijedudev.2011.12.001.x

Moloi, T.J. (2014). The use of Morabaraba to Concretise the teaching of the Mathematical Content. Mediterranean Journal of Social Science, 5(27).585-591.

Mulaudzi, N.O. (2016). An investigation on the role of grade $R$ teachers in creating a conducive environment for learning numeracy at Vhurongathe Vhembe district in South Africa. Unpublished PhD Thesis, University of South Africa, Pretoria. 
Madimabe, M. P. \& Omodan, B. I. Investigating the Effects of E-Learning as A Method of Curriculum Dissemination for Rural TVET College Students

Omodan, B. I. (2020). The vindication of decoloniality and the reality of COVID-19 as an emergency of the unknown in rural universities. International Journal of Sociology of Education, 20, 1-26. http://doi.org/10.17583/rise.2020.5495.x

Okoye, K., Rodriguez-Tort, J. A., Escamilla, J., \& Hosseini, S. (2021). Technology-mediated teaching and learning process: A conceptual study of educators' response amidst the Covid-19 pandemic. Education and Information Technologies, 1-33. https://doi.org/10.1007/s10639-021-10527-x

Omodan, B. I., Tsotetsi C. T., \& Dube, B. (2019). Decolonising rural-urban dichotomy in South Africa: An asset-based approach. Progressio: South African Journal for Open and Distance Learning Practice, 41(1), 1-17.

Picciano, A. G. (2017). Theories and frameworks for online education: Seeking an integrated model. Online Learning, 21(3), 166-190. http://doi.org/10.24059/olj.v21i3.1225.x

Salamat, P., Ahmad, L., Bakht, I.G., \& Saifi, I.L. (2018). Effects of e-learning on students' academic learning at the university level. Asian Journal of Social Sciences \& Humanities, 2(2), 1-12.

Sapungan, M.G., \& Sapungan, M. R. (2014). Parental involvement in Child's Education: Importance, Barriers and Benefits. Asian Journal of Management Sciences \& Education, 3, 42-48.

Siemens, G. (2005). Connectivism: A learning theory for the digital age. International Journal of Instructional Technology and Distance Learning, 2(1), 1550-6908.

Shrivastava, A. (2018). Using connectivism theory and technology for knowledge creation in cross-cultural communication. Research in Learning Technology, 26, 1-16.

Unwin, T. (2009). Information and communication technology for development. Cambridge: Cambridge University Press.

Zawacki-Richter, A., \& Qayyum, A. (2019). Open and distance education in Asia, Africa and the Middle East: National perspectives in a digital age. Springer Briefs in Education. http://www.springer.com/series/15238

Zare, M., Sarikhani, R., Salari, M., \& Mansouri, V. (2016). The impact of e-learning on university students' academic achievement and creativity. Journal of Technical Education and Training, 8(1), 25-33. 